\title{
SPORTS MEDICINE
}

\section{SPORTGENEESKUNDE}

\author{
JOURNAL OF THE S.A. SPORTS MEDICINE ASSOCIATION \\ TYDSKRIF VAN DIE S.A. SPORTGENEESKUNDE-VERENIGING
}

\begin{tabular}{lll}
\hline VOLUME 6 & NUMBER 3 & JUNE/JULY 1991 \\
\hline
\end{tabular}

National Advisorv Board

Editor in Chief:

Clive Noble

Associate Editors:

Prof TD Noakes

Dawie van Velden

Advisory Board:

Traumatology:

Etienne Hugo

Physiotherapy:

Joyce Morton

Nutrition:

Mieke Faber

Biokinetics:

Martin Schwellnuss

Epidemiology:

Derek Yach

Radiology:

John Straughan

Physical Education:

Hannes Botha

Internal Medicine:

Francois Retief

\section{International Advisory Board}

Lyle J Micheli

Associate Clinical Professor of

Orthopaedic Surgery

Chester R Kyle

Research Director, Sports

Equipment Research Associates

Prof HC Wildor Hollmann

Präsident des Deutschen

Sportärztebundes

Howard J Green

Professor, Department of

Kinesiology

George A Brooks

Professor, Department of Physical

Education

Neil $F$ Gordon

Director, Exercise Physiology

Edmund $R$ Burke

Associate Professor, Biology

Department, University of

Colorado

Graham N Smith

Physiologist

\section{CONTENTS}

\section{Editorial Comment}

Health care in the new South Africa .............. 3

Psychology

Psychological dimensions of sports injuries ...... 4

\section{Cricket}

Cricket injuries - A review

\section{Nutrition}

The effect of dietary cholesterol on plasma

cholesterol levels

\section{SASMA Update}

SASMA news

\section{Physiotherapy}

Treatment of soft tissue injuries: the facts

about frictions.

The Comrades Marathon as seen through

the eyes of a physiotherapist

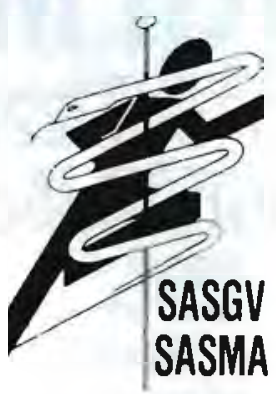

JOURNAL OF THE SOUTH AFRICAN SPORTS MEDICINE ASSOCIATION 269 WEST AVENUE

HENNOPSMERE

VERWOERDBURG, 0157

The Journal of the SA Sports Medicine Association is published by Medpharm Publications, 3rô Floor Noodhulpliga Centre, 204B HF Verwoerd Drive, Randburg 2194. PO Box 1004, Cramerview 2060. Tel: (011) 787-4981/9. The views expressed in this publication are those of the authors and not necessarily those of the publishers. 
The complete one-a-day Multivitamin and Mineral supplement

Emvit’ keeps you Going!

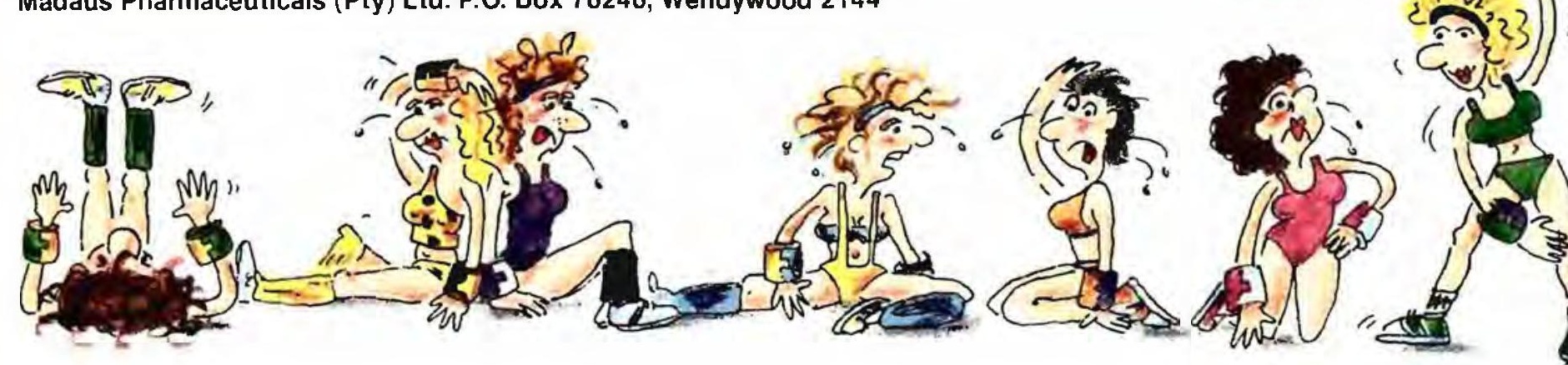

Keep ahead with ${ }^{(s)}$ Reparil- $-G_{6}$

$100 \mathrm{~g}$ contains: Aescin 1,0g; Aescin sodium polysulphate (heparinoid) 1,0g; Diethylamine salicylate 5,0g.

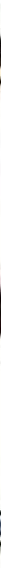

Get up and go with Magnesit

Magnesium - $\ell$ - aspartate $\mathrm{Hcl} 1229,6 \mathrm{mg}$

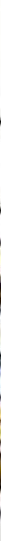




\section{HEALTH CARE IN THE NEW SOUTH AFRICA}

In the New South African health care for all will become the order of the day. With the unlikelihood of much additional funding being available to achieve this, one must look at the effects this will have on sports medicine.

The major cost in sports medicine is the treatment of sports injuries. Thus, if treatment can be avoided by prevention, a great saving can be achieved. Improved facilities and coaching

techniques to all race groups would go a long way in this regard. This would not form part of the health budget.

At this point in time, sports medicine facilities are part of South Africa's first world, i.e. for whites and blacks on medical aid as well as the richer black soccer clubs that can afford such facilities. Most other injured blacks are treated by witch-doctors with the tell-tale scratches occurring on the injured part. Seeing that many sports injuries get better with time alone, in the past this was acceptable "therapy". However, with Aids becoming a major problem this method of treatment will cause Aids to spread unless adequate sterilisation procedures are observed. Also, Aids becomes important in sports where bleeding may occur such as boxing and other collision sports. Adequate precautions such as the use of rubber gloves by the seconds and referee, or stopping of a fight once bleeding occurs, may become mandatory.

The answer to most of the sports medicine requirements is education grass roots level. All coaches and trainers should do a course in first aid with a sports medicine bias. They should also have a knowledge of rehabilitation, knowing when an injured player can return to sport with the least chance of reinjury. First aid should be available at all sporting venues. This can be done without over straining the resources of the first aid groups by, for example, at school level having children who are unable to play sport because of ill health or other reasons join the team as first aiders. Similarly at clubs, supporters can be turned into first aiders. A minimum standard of equipment can be set without overburdening the club or schools finances.

These same school first aiders can, with time, improve their knowledge and in rural areas become primary health personnel running clinics which can then refer problems to peripheral

hospitals. They may also become nurses or even doctors so vital in the new South Africa.

Paramedical education can also be extended to the third world. Sports medicine should also form a larger part of medical training at our universities and colleges, both for doctors and

nurses. Sports medicine diplomas and degrees should be available at all universities with medical schools. Departments of Sports Medicine at all medical schools should be mandatory. This would ensure better healthcare for all our sportsmen and women.

A utopia ..... maybe.

Dr Clive Noble MBBCh, FCS (SA) Editor-in-Chief 


\title{
PSYCHOLOGICAL DIMENSIONS OF SPORTS INJURIES
}

\author{
JR Potgieter
}

The many excellent books and journals published in recent years bear testimony to progress in the field of sports medicine during the past decade. Closer inspection of these texts, however, reveals a dearth of literature on the psychological dimensions of the rehabilitation of injured sportsmen. Although this is not a healthy state of affairs, it is, nevertheless, not surprising. The causes of sports injuries are primarily of a physical nature. However, psychological factors should not be discounted.

Sportsmen are practical people and work hard and in a disciplined way on their physical conditioning and skills. Although they invariably recognise the importance of psychological dimensions in sport, psychological training occupies a relatively minor place in most training regimens. In addition, in the world of sports there is some resistance to utilising the services of so-called sport psy-

\section{JR Potgieter}

\section{Department of Human}

Movement Studies University of Stellenbosch chologists to enhance physical performance. The process of sport socialisation makes it difficult for the sportsman to enlist the services of a psychologist, because such a step is out of line with the accepted values of sports participation such as toughness, determination, persistence, assertiveness and aggression. The "old school " approach creates a milieu that could perceive the consultation of a psychologist as a sign of weakness. Research has verified this assumption (Carmen et al, 1968; Linder et al, 1989; Pierce, 1969; Scanlan et al, 1989).

\section{NEED FOR A PSYCHOLOGICAL APPROACH}

If it is true that the average healthy sportsman is reluctant to consult a psychologist it is not surprising that he is also apprehensive to seek psychological assistance when injured. Along with the improved treatment of injured sportsmen it has, however, become important to focus on the psychological dimensions of rehabilitation. Because the sportsman can nowadays return to an active programme after a relatively short period of time, psychological complications may arise. In many cases this shortened rehabilitation time may not be long enough for the injured sportsman to adjust psychologically. He may be physically ready for re-entry into the sports arena but his mental adjustment has not been completed. The traumatic reminders of his injury are still fresh in his memory while, at the same time, extemal demands are placed on him to perform physically. Anxiety and selfdoubt as well as real fears of a recurrence of the same injury or an injury to another part of the body may plague him (Rotella \& Heyman, 1986). The fact that serious competitors are highly committed and make significant investments in their sport, makes these fears even more significant.

Rehabilitation of the injured sportsman is therefore both a physical and psychological process. It follows that the sportsman as a whole should be treated and not only the injury. Because the emotions are involved, sports medicine professionals need to attend to the psychology of the injured sportsman (Eldridge, 1983).

\section{REACTIONS TO INJURY}

At the outset it must be pointed out that many sportsmen do not 
need any special psychological treatment. Sportsmen react to injury in different ways. With a sound physical rehabilitation programme and the necessary support and encouragement most sportsmen are able to overcome their injuries successfully and without any significant negative effects. Some may even view their injuries as a further opportunity to display courage, commitment, self-discipline and perseverance. In contrast, for others, injury could provide a break from a taxing training regimen and an escape from the demands placed on them (Rotella \& Heyman, 1986). It provides an excuse for below par performances. However, for others an injury could present a true crisis where psychological intervention is indicated (Little, 1979).

\section{STRESS AS A PREDISPOSING FACTOR}

Research findings strongly suggest that there is a relationship between stressful life events or even ordinary daily hassles and a sportsman's predisposition to injury (Bramwell et al, 1975; Coddington \& Troxel, 1980; Cryan \& Alles, 1983; Passer \& Seese, 1983). Although most of the research has been done on contact sports, such as football, there are indications that this relationship also holds for noncontact sports (Kerr \& Minden, 1988). It is hypothesised that the presence of these stressful events decreases the sportsman's coping ability (Miller et al, 1990). Daily hassles demand attention and the resulting division of atten- tion between stressful events and the task at hand can be a cause of injury. The mere physical fatigue resulting from a stressful life can be a logical answer for an increase in injuries among sportsmen who are experiencing daily stress.

The occurrence of injuries at critical times just prior to an important competition cannot be explained with certainty. It may merely be the result of intensified training, but a possible cause could be attributed to the heightened stress as the day of an important competition approaches. Because avoiding injury prior to such competitions is of immense importance, it is advisable in some cases to assist sportsmen psychologically to counter the effects of daily stress. Andersen and Williams (1988) suggest that it may be necessary to assess a sportsman's coping behaviours such as sleep patterns, nutritional habits, time management, general self-esteem and if the athlete is a student, study skills. The use of stress management programmes, relaxation techniques, cognitive restructuring, and social support can enhance the coping skills of the sportsman.

\section{UNDERSTANDING THE WORLD OF THE INJURED SPORTSMAN}

Empathy is a key concept in the rehabilitation of the injured sportsman. The therapist and coach can enhance this empathy by understanding the world of the participant and what it means to him. Participation in regular exercise and sport has the potential to enhance psy- chological well-being (Sachs, 1984). The participant not only derives enjoyment and satisfaction from sport but also derives feelings of competence and control. Furthermore, participation in sport and physical exercise may serve as an important way of reducing stress and dealing with depression. When considering the psychological and social benefits, it is not surprising that a sudden termination of participation could be a traumatic experience for the sportsman. This provides a partial explanation of why injured sportsmen, against medical advice, continue to participate in activities such as running. It is suggested that these individuals find it more acceptable to handle the physical discomfort and pain associated with continued participation than dealing with the psychological tension, anxiety and depression associated with non-participation (Smith et al, 1990b). It is logical to assume that the stronger the athlete's preoccupation with health and fitness, the more intense these negative manifestations of exercise deprivation will be.

Another phenomenon that must be kept in mind by the therapist, is the tendency of many a sportsman to tie his identity and worth as a person to his sports participation and sports achievements (Joseph \& Robbins, 1981). A significant part of his daily interaction with other people is done as a sportsman. He sees himself as a sportsman and other people. treat him as such. When his sports participation is temporarily or permanently discontinued a loss of identity can 
occur. As a result it is not uncommon for sportsmen to suffer a loss of self-esteem when injured.

\section{EMOTIONAL REACTIONS TO INJURY}

There are suggestions that injured sportsmen proceed through emotional stages similar to those experienced by the terminally ill. The limited sports research that has been done on the so-called loss-ofhealth models shows that these could be applied to some extent to injured sportsmen. Ogilvie and Howe (1986) maintain that sportsmen who are forced to terminate their athletic carcers proceed through emotional stages similar to those proposed by Kübler-Ross (1969).

Denial is the first phase that the injured sportsman enters. He may deny the seriousness of his injury and fail to accept the fact that he will be out of action for an extended period of time. This is also a common phenomenon among sportsmen who have to terminate their sporiing careers for reasons other than injuries, for example if they are no longer able to perform up to standard. A manifestation of this denial and unwillingness to accept the fact that they have come to the end of their sporting careers is an intensification of physical training and an even more regimented lifestyle than before. However, not all sportsmen experience this phase. Smith et al (1990a) observed emotional reactions among injured sportsmen similar to that proposed by Kübler-Ross but did not encounter denial as a phase. They suggested that sportsmen who persist in playing when injured do not deny pain as such, but are motivated to continue participating for more complex reasons.

When denial is no longer effective in dealing with the effects of an injury, anger may characterise the next stage. The unfortunate aspect of this stage is that anger and rage are often directed at those people who are close to the sportsman, such as his family, team-mates and coach. This anger is often generalised to include God, society, and life in general. Anger can also be directed inwards. The injured sportsman may become excessively self-critical, blaming himself for his condition. This anger may manifest in selfdestructive behaviour such as alcohol and drug abuse.

During this second stage the sportsman becomes irritable and difficult to work with. An otherwise coachable and reasonable person can become aggressive and negative. This stage could also be characterised by irrational thinking. The injured sportsman can disregard important aspects of his injury or he can oversimplify the situation. A further form of irrational thinking is overgeneralisations and unwarranted conclusions. He may reason that because another person did not recover successfully, he will not succeed either. He may even conclude that the therapist and coach are not interested in his progress or are not giving equal attention to his problems. An understanding coach and therapist should approach such a person with a great deal of empathy and patience.
Although the reactions of denial and anger may be intense they are usually of a short duration and the sportsman moves into the next stage of reactive depression. He typically withdraws and isolates himself. This reaction is understandable because the sportsman is confronted with a major change in lifestyle. $\mathrm{He}$ has invested a great deal of his life in his sport and shows a type of grief response (Pedersen, 1986; Weiss \& Troxel, 1986). The sad aspect of this reaction is that the athlete isolates himself from the social support of important other people, who he in fact needs to help him on the road to recovery. He avoids his coach and tcam-mates and experiences a feeling of helplessness and loneliness in this situation that he has created himself. His life may lose much of the meaning it had before his injury. If this condition persists over an extended period of time special counselling may be necessary (Ogilvie \& Howe, 1986).

Although the feeling of isolation is generally the resuli of the sportman's own behaviour, some coaches may contribute to this. Coaches may fail to keep in touch with the injured athlete or fail to show a continued and active interest in his progress. There are even coaches who deliberately make the injured athlete feel worthless in an attempt to speed up his return to the playing field.

It is not uncommon for injured sportsmen to experience feelings of guilt. They may feel that they are letting their team and coach down. Ruthless coaches may exploit the 
athlete's loyalty and commitment to get him back on the field as soon as possible.

To counteract these feelings of loneliness and isolation it is expedient that normal contacts should be resumed as soon as possible. Social support is a critical element in enhancing treatment adherence (Duda et al, 1989; Fisher, 1990). Andersen and Williams (1988) propose that the presence of a supportive social network (which includes the physician) may directly protect the sportsman against injury or may attenuate the effect of the stress brought about by daily hassles and the stressfulness of competitive sport.

The injured sportsman should rejoin his team as early as possible. Although it may be impossible to physically participate in practice ses- sions, he can attend team discussions and scrimmages. It is further suggested that he adopts a routined lifestyle similar to that which he followed prior to his injury.

A knowledge of the emotional struggles of the injured sportsman can assist the coach and therapist in showing greater empathy. It is important that this empathy is communicated to the athlete. $\mathrm{He}$ should be told that it is understood and accepted that the injury is inconvenient and that he feels disappointed, frustrated, impatient and at times angry. On the other hand, it should be pointed out to him that it is irrational to punish himself and others. Open aggression toward others, especially those who are able to help him is not acceptable. It is also irrational to view his slow progress as a sign of weakness.

The final stage that follow's injury is acceptance of reality with the hope that somehow everything will turn out for the best.

\section{LOCUS OF CONTROL}

Locus of control can play a significant role in the sportsman's perception of his injury and his rehabilitation. An internal locus of control refers to the extent an individual believes that he has control over his life. In contrast, an external locus of control is characterised by a perception that one's life is controlled and determined by factors outside oneself, such as fate, luck, change and powerful other people. The individual with an external locus of control feels
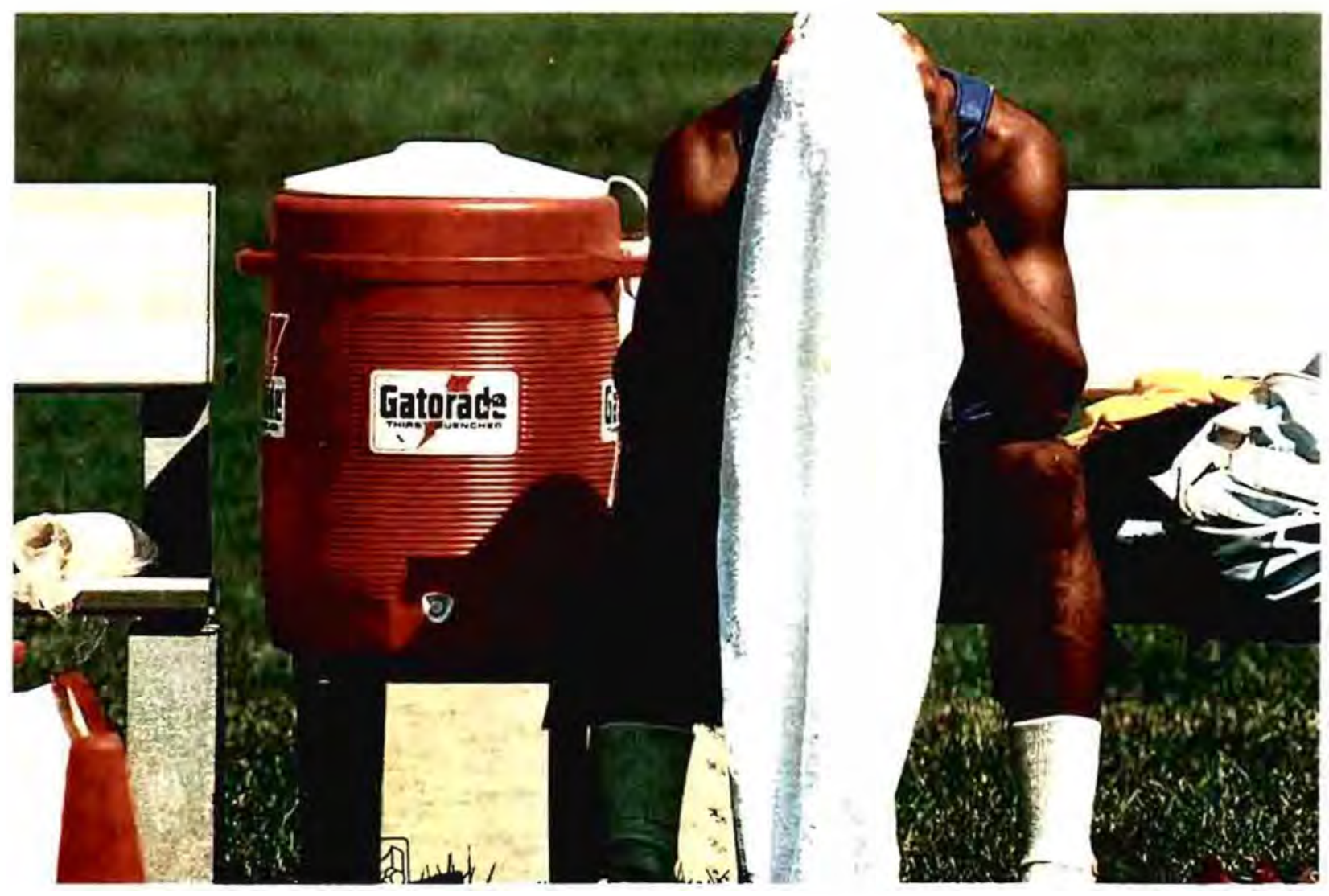
that he is helpless and does not have control over his own life. Sportsmen generally have a strong internal locus of control. It is therefore important that this locus of control be maintained during the rehabilitation process.

Sportsmen who have emotional control will function more effectively if they are treated in a rational manner. They will exert better control over their progress if they are provided with knowledge about their injury and the rehabilitation process. It has been established that adjustment problems in the rehabilitation of cardiac patients is related to uncertainty about their condition (Christman, 1988). Similarly, uncertainty could retard the rehabilitation of the injured sportsman. Apart from keeping the athlete informed about his injury and his progress, it is suggested that the athlete is involved in the planning of his rehabilitation. The process of goal setting has relevance here.

Although the injured sportsman should be involved in his own rehabilitation, Fisher (1990) warns that the motivation and adherence to persist with a rehabilitation programme is not the sole responsibility of the person being treated. In fact, the attitude of the therapist may be self-fulfilling. The more nonadherence the therapist expects the less he will be motivated to change the behaviour of the injured sportsman if he perceives the responsibility as being the patient's alone. This motivation can be reduced by failing (a) to adequately explain the injury and proposed treatment, (b) to request the sportsman's assistance in the programme, (c) to monitor progress, and (d) to motivate the sportsman when necessary.

\section{CONCLUSION}

While many sportsmen cope effectively with injury there are others who need special attention to adjust psychologically. An understanding of the emotional reactions that follow an injury could lead to greater empathy with the sportsman. Social support, encouragement and the maintenance of normal relationships could have a significant effect on the rehabilitation process. Keeping the athlete informed about the nature of his injury and the purpose and progress of rehabilitation could enhance recovery. REFERENCES

1. Andersen MB and Williams JM. A model of stress and athletic injury: Prediction and prevention. Journal of Sport and Exercise Psychology, 1988; 10: 294-306

2. Bramwell ST, Masuda M, Wagner NN and Holmes TH. Psychological factors in athletic injuries. Journal of Human Stress, 1975; 2: 6-20.

3. Carmen $\mathrm{L}$, Zerman JL, and Blaine GB. The use of the Harvard psychiatric service by athletes and nonathletes. Mental Hygiene, 1968; 52.

4. Christman NJ. Uncertainty, coping and distress. Research in Nursing and Health, 1988; 11, 71-82.

5. Coddington RD and Troxel JR. The effects of emotional factors on football injury rates: A pilot study. Joumal of Human Stress, 1980; 7, 3-5.

6. Cryan PD and Alles WF. The relationship between stress and college football injuries. Journal of Sports Medicine, 1983; 23, 52-58.

7. Duda JL, Smart AE and Tappe MK. Predictors in adherence in rehabilitation of athletic injuries: An application of personal investiment theory. Journal of Sport and Exercise Psy. chology 1989; 11, 367-381.

8. Eldridge WD. The importance of psychotherapy for athletic-related orthopaedic injuries among adults. International Journal of Sport Psychology, 1983; 14, 203-211.

9. Fisher CA. Adherence to sports injury rehabilitation programmes. Sports Medicine 1990; 9, 151-158.

10. Joseph $P$ and Robbins JM. Worker or runner? The impact of commitment to running and work on selfidentification. The psychology of running, 1981; pp. 131-145. MH Sacks and M Sachs (eds.). Champaign, IL: Human Kinetics.

11. Kerr G and Minden H. Psychological factors related to the occurrence of athletic injuries. Journal of Sport and Exercise Psychology. 1988; 10, 167-173.

12. Kübler-Ross E. (1969). On death and dying. New York: MacMillan.

13. Linder DE, Pillow DR, Reno RR. Shrinking jocks: Derogation of athletes who consult a sports psychologist. Journal of Sport and Exercise Psychology, 1989; 11, 270-280.

14. Little JC. Neurotic illness in fitness fanatics. Psychiatric Annals, 1979; 9, 148-152.

15. Miller TW, Vaugh MP and Miller JM. Clinical issues and treatment strategies in stress-oriented athletes. Sports Medicine, 1990; 9, 370-379.

16. Ogilvie $B C$ and Howe $M$. The trauma of termination from athletics. $A p$ plied sport psychology. Jean M. Williams (ed.). 1986; pp. 365-382. Palo Alto, CA: Mayfield.

17. Passer MW and Seese MD. Life stress and athletic injury: Examination of positive versus negative events and three moderator variables. Journal of Human Stress, 1983; 10, 11-16.

18. Pedersen $P$. The grief response and injury: A special challenge for athletes and athletic trainers. Athletic Training, 1986; 21, 312-314.

19. Pierce RA. Athletes in psychotherapy: How many, how come? Journal of the American College Health Association, 1969; 17, 244-249.

20. Rotella $\mathbf{R}$ and Heyman SR. Stress, injury, and the psychological rehabilitation of athletes. Applied sport psychology. Jean M. Williams (ed.) 1986; pp. 343-364. Palo Alto, CA: Mayfield.

21. Sachs ML. Psychological well being and vigorous physical activity. Psychological foundations of sport, 1984; pp. 435-444. JM Silva III and RS Weinberg (eds.). Champaign, IL: Human Kinetics.

Other references on request. 


\title{
CRICKET INJURIES - A REVIEW
}

\author{
Richard Stretch
}

Reviews of sporting injuries have tended to concentrate on contact sports, with reports and research on cricket injuries receiving little attention, mainly being conducted as part of other analysis and being published in medical journals. This has resulted in the majority of cricket administrators, coaches and players not being aware of the nature, incidence, cause and risk factors associated with playing a game that is demanding more physical output than previously. It was for this reason that a review of cricket injuries was conducted.

The British Sports Council estimated the risk of injuries to club cricket players to be 2,6 per 10000 man hours played. ${ }^{1,2}$ These figures excluded injuries thought to be trivial, as well as many chronic overuse injuries. The rate of injury to first class cricketers in Australia was estimated to be 1 per 30 man-hours played. ${ }^{3}$ South African provincial and international cricketers $(71,6 \%)$ were found to be at a greater risk of

\section{Richard A Stretch MA}

Department of Human

Movement Studies

University of Fort Hare

Private Bag X1314

Ciskei injury than club cricketers $(28,4 \%) .^{4}$

Deaths from cricket date back, according to cricket lore, to the passing of Frederick Louis, the Prince of Wales and father of George III, who died hours after being struck on the head by a cricket ball. ${ }^{2}$ Blonstein $^{5}$ suggests that six deaths per year occurred in the United Kingdom as a result of playing cricket. However, these figures should be considered with reservation. ${ }^{3}$

The major portion of serious injuries were sustained during matches $(69,3 \%)$, with $26,1 \%$ occurring during practices and $4,6 \%$ during both matches and practices. ${ }^{4}$ The injuries occurred fairly regularly throughout the season, with a slight increase during the early and latter part of the season, ${ }^{4}$ overuse injuries more common towards the end of the season. ${ }^{6}$

The incident of injury to the head, neck and face varied from $9 \%$ in club and provincial players, ${ }^{4} 20 \%$ in provincial players ${ }^{7}$ and $25 \%$ in club cricketers. $^{2}$ Concussions, contusions, lacerations and nose bleeds were the most common. Eye injuries in cricket were reported as long ago as the beginning of the century, ${ }^{8}$ with later cases of chronic glaucoma secondary to trauma ${ }^{9}$ and ocular concussion, ${ }^{10}$ reported. Five cases of severe eye injuries, including retina detachment and rupture of the globe, were documented in batsman and close fielders. " This accounted for $9,0 \%$ of sport related eye injuries. A survey over 18 months carried out at the Sussex Eye Hospital revealed five minor eye injuries caused by playing cricket which accounted for $5,4 \%$ of all sporting eye injuries recorded. ${ }^{12}$ Coroneo $^{13}$ recommended that ocular protective devices be worn when playing indoor cricket after reporting four cases of ocular injuries in cricketers.

The upper limb accounted for $25 \%$ of injuries in club cricketers, ${ }^{2} 32 \%$ in provincial cricketers $^{7}$ and $34 \%$ in provincial and club cricketers. ${ }^{4}$ The fingers were found to be the most vulnerable site for injuries. ${ }^{1,2,4,6,14,15}$ These injuries consisted primarily of fractures, dislocations and contusions while batting and fielding. "Throwers shoulder" which is caused by degene- ration and inflammatory changes or partial and complete ruptures of the rotator cuff was also found to be a common cricket injury, ${ }^{16}$ while Clay Shoveller's fracture was recorded as a result of playing cricket. ${ }^{17}$

Back and trunk injuries accounted for approximately $18 \%$ of the serious and $14 \%$ of the less serious injuries. ${ }^{4.7}$ The case of a splenic rupture as a result of being struck by a cricket ball was reported. ${ }^{18}$ Young fast bowlers were found to be vul- 
nerable to lower back injuries, ${ }^{19}$ while the case of a young fast bowler who developed acute pneumomediastinum and bilateral pneumothoraces while practising fast bowling was reported. ${ }^{20}$

Many injuries occur in the lower limbs due to impact from the ball, stress injuries associated with repetitive movements and other injuries normally associated with field sports. The findings varied from $25 \%,{ }^{2} 30 \%^{7}$ and $38 \% .^{4}$ The unusual case of two brothers sustaining serious injuries in the same pre-match fielding practice session was documented. ${ }^{21}$ The first sustained a medial meniscus injury which had to be excised arthroscopically and the other a transverse fracture of the middle third of the femur.

Bowling has been found to be the major cause of injuries, varying from $38 \%$ in young schoolboy players, ${ }^{19} 42,0 \%$ in club and provincial cricketers ${ }^{4}$ to $65,7 \%$ in provincial cricketers. ${ }^{7}$ These were found to be predominantly lower back injuries, 4.7,19,22 muscle tears, especially of the hip flexor, the adductor longus of the leg and the rectus femoris muscles, 6.16 and over-use injuries. ${ }^{4,7,19,22}$ Serious injuries, mainly to the lower back of a number of elite and junior fast bowlers, were caused by a combination of the forces at front foot impact and a front-on bowling action. ${ }^{19}$ Spondylolysis was found to be common in Australian fast bowlers playing first class cricket. ${ }^{6}$ This injury is due to a stress fracture that occurs to the parts interarticulans on the side opposite the bowling arm as a result of the rotation and extension of the back when bowling fast. Stress fractures are common in fast bowlers and occur primarily in the metatarsal bones, the fibula and tibia. ${ }^{6}$ Other common over-use injuries include abdomen muscle tears, ${ }^{6}$ shoulder injuries, ${ }^{7}$ talotibial exostoses, patellar tendonitis ${ }^{6}$ and bruised heels and "shin splints". 4,6,7

Batting accounted for $17,1 \%$ of the injuries ${ }^{4}$ with muscle pulls and impact injuries being the most common. ${ }^{4,7}$ The majority of head injuries were as a result of being struck by the ball while attempting to hook, by the ball deflecting off the top-edge of the bat on to the head while playing a horizontal-bat stroke, or as a result of being struck by the ball rearing off the pitch. ${ }^{7}$ These injuries were sustained while the batsmen were batting without a helmet or with a helmet with ear-pieces only, respectively and inciuded concussions, broken nose and cheek bones and lacerations, requiring stitches around the eyes, mouth and chin. Four of the eye injuries reported by Jones and Tullo ${ }^{11}$ were as a result of the ball deflecting off the top edge of the bat while hooking and striking the eye on the side of the dominant hand. The danger of a fracture, as a result of being struck by the ball while batting, to the distal third of the ulnar, rib fractures and soft tissue injuries, especially to the upper leg, abdomen and testicles were reported. ${ }^{6}$ The topand middle-order batsmen were found to be more susceptible to impact injuries to the head, phalanges, metacarpals and lower arm injuries than the lowerorder batsmen, ${ }^{7}$ while Payne ${ }^{3}$ reports that bowlers sustained most impact injuries while batting. Lower limb injuries were mainly hamstring, quadriceps and calf muscle pulls as a result of running between the wicket. ${ }^{1-}$ 4,7

Fielding and catching resulted in $40,9 \%$ of the serious injuries with $63,9 \%$ impact injuries to the upper limbs. ${ }^{4}$ Corrigan $^{6}$ reported three cases of ruptured spleens sustained when, attempting to catch or field a ball, they landed heavily on their left side. "Throwers shoulder" can prove to be one of the most troublesome injury to cricketers. ${ }^{6,22}$ Five, out of nine shoulder injuries sustained occurred while fielding. ${ }^{7}$

Twenty-five percent of the serious injuries resulted in the players being out of the game for more than twenty-one days, while $47,8 \%$ and $27,2 \%$ were not able to practice or play for between one and seven days and eight and twenty-one days, respectively. ${ }^{4}$ Injuries to the upper and lower limbs were the most serious in terms of days missed with nine injuries to each region preventing the players from playing for twentyone days or more. ${ }^{4}$ The upper limb injuries to the club cricketers resulted in an average of five days being lost to play, with a range of between 0 to fifty-six days, while an average of six days were lost to play as a result of injuries to the lower limbs. ${ }^{1}$ The head and facial injuries ${ }^{1,4}$ and the back and trunk injuries ${ }^{4}$ generally enabled the cricketers to return to the game within seven to nine days of injury. The length of recovery time varied with the level at which the players competed.

Many of the injuries sus- 
tained were either re-occurring injuries from the previous season or re-occurred again later in the season. Twenty percent of the injuries sustained on an international tour were reaggravated injuries from the previous season, ${ }^{23}$ while $23,9 \%$ of the injuries to be reoccurrence of old injuries and $22,7 \%$ of the new injuries sustained were re-aggravated again during that season. ${ }^{4}$

Payne $^{3}$ reported an increase in over-use injuries in young children, especially in the areas of stress fractures and growth cartilage injuries. The primary areas of concern, particularly to the fast bowlers, were found to be damage to the growth cartilage of the knee and traction apophysis, and compressive stress to the articular surface cartilage of the femur and talus. Thirty-eight percent of young fast bowlers were found to have suffered one disabling injury during a single season, with stress fractures of the lumbar and/or sacral vertebrae $(11 \%)$, and soft tissue injuries to the back (27\%) causing them to miss at least one match. ${ }^{19}$ Du Toit and Rademan $^{18}$ reported the case of a 14-year-old boy requiring splenectomy for a ruptured spleen after blunt trauma from a cricket ball. The case of a young fast bowler who developed acute pneumomediastinum and bilateral pneumothoraces while practising fast bowling was reported by Clements and Hamilton. ${ }^{20}$ The younger players tended to be at the greatest risk to injury with $53,3 \%$ and $51,4 \%$ of those in the age groups below 21,1 years and between 21,1 and 26,2 years, respectively, sus- taining some form of serious injury. ${ }^{4}$

The less serious injuries were mainly strains of the groin, hip, hamstring, quadriceps and back muscles, finger injuries, twisted ankles, shin splints, blisters, abrasions and bruised feet, heels and fingers.

Forward ${ }^{24}$ recorded all the indoor cricket injuries that were reported at the Royal Perth Hospital during a sixmonth period. He found that of the sixty-four patients treated all fell in the $19-34$ year age group, with fourteen of these being women. Fielding (72\%) and batting $(17 \%)$ resulted in the major share of these injuries, while no injuries were sustained while bowling. The most common injuries were to the fingers and thumb. Knee and ligamentous strains of the ankle while twisting to catch or avoid the ball, as well as eye injuries to wicket-keepers as a result of being struck by the ball after deflecting off the edge of the bat, were fairly common. Fifty percent of the injured players required time off work, with thirty percent being off work for more than a week and ten percent being hospitalised.

From the literature reviewed it is evident that the incidence of cricket injuries, particular over-use injuries and those normally associated with field sports, is an underrecognised problem. Appropriate injury records and data collection need to be introduced. This would enable coaches, players and those involved in treatment and rehabilitation, to successfully bring about the reduction, prevention, treatment and rehabilitation of these injuries.

\section{REFERENCES}

1. Weightman D and Browne RC. Injuries in eleven selected sports. British Journal of Sports Medicine, 1971; 2 : 27.

2. Temple R. Cricket Injuries: Fast pitches change the gentleman's sport. The Physician and Sports medicine, 1982; 10(6): 186-192.

3. Payne WR, Hoy G, Laussen SP and Carlson JS. What research tells the cricket coach. Sports Coach, 1987; 10(4): 17-22.

4. Stretch RA. Somatotype and body composition changes in first-class cricketers. Paper presented at "International Congress on Youth, Leisure and Physical Activity and Kinanthropometry IV", Brussels, Belgium, 21-25 May 1990.

5. Blonstein JL. Medical aspects of amateur boxing. Proc R Soc Med, 1966; 59: 6499.

6. Corrigan AB. Cricket Injuries. Australian Family Physician, 1984; 13(8): 558-562.

7. Stretch RA. Injuries to South African cricketers playing at first-class level. Sports Medicine, 1989; 4(1): 3-20.

8. Ogilvie FM. On one of the results of concussion injuries of the eye ("holes" at the macula). Trans Opthalmol Soc $U K, 1900$; 20: 202-229.

9. D'Ombrain A. Traumatic monocular chronic glaucoma. Trans Opthamol Soc, Australia, 1945; 5: 116120.

10. Littlewood KR. Blunt ocular trauma and hyphaema. Australian Journal of Ophthalmology, 1982; 10: 263266.

11. Jones NP and Tullo AB. Severe eye injuries in cricket. British Journal of Sports Medicine, 1986; 20(4): 178 179.

12. Gregory PTS. Sussex Eye Hospital sports injuries. British Journal of Ophthalmology, 1986; 70: 748-750.

13. Coroneo MT. An eye for cricket ocular injuries in indoor cricketers. The Medical Journal of Australia, 1985; 142: 469-471.

14. Nel D, Smit PJ and Stoker DJ. Die invloed van sportsbeserings op sportdeelname en werk. South African Medical Journal, 1979; 53: 426428 .

15. Williams JGP. Joint Injuries. In: I Cohen, GR Beaten and D Mitchell (Eds). The South African Texibook of Sports Medicine, University of Witwatersrand, Johannesburg, 1979.

Other references on request. 


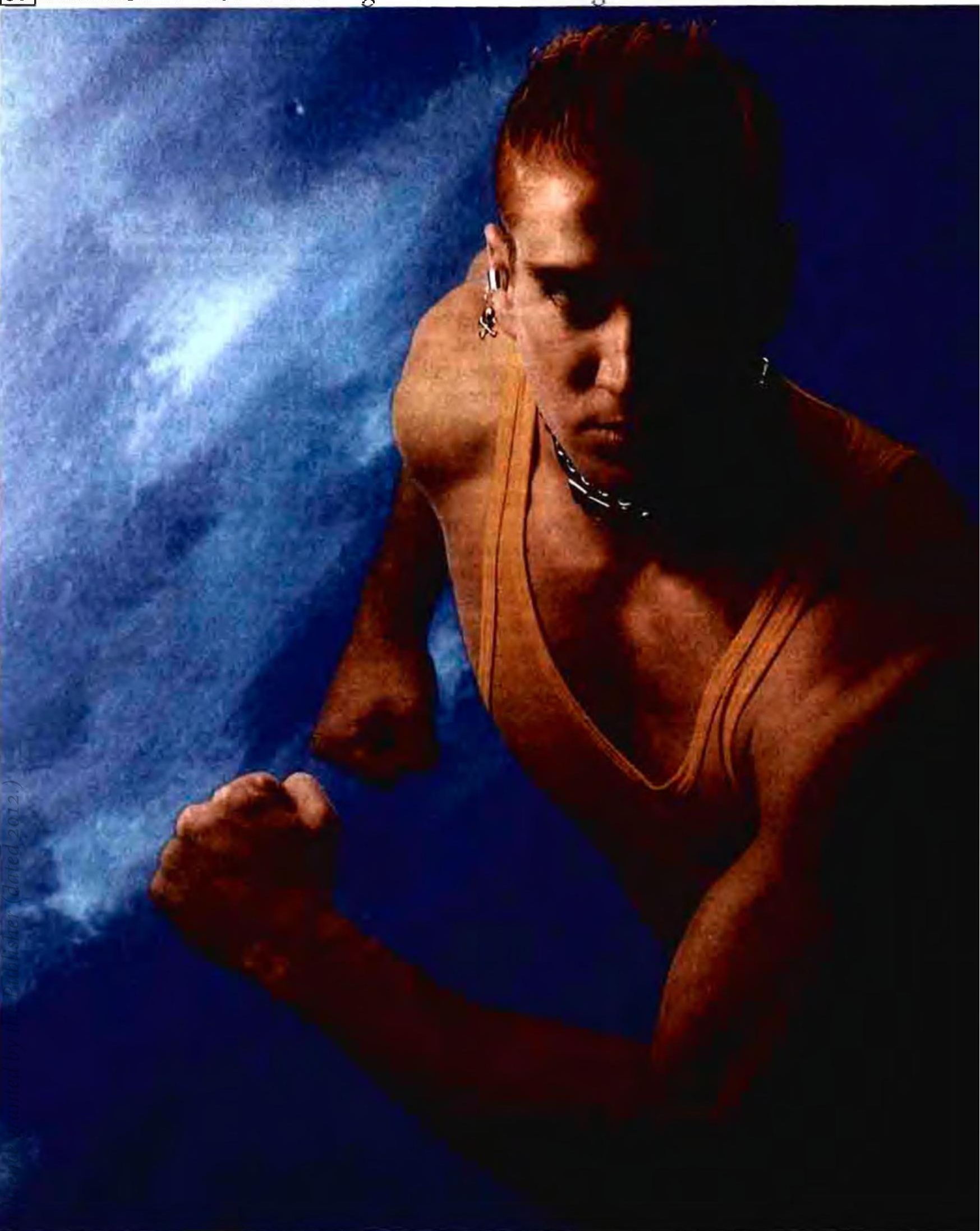

When your patient's in pain, your first responsibility is to take away that pain. Quickly. Effectively.

But doing so could lead to unacceptable gastrointestinal side effects and combination therapy.

But now, ten years of precisely targeted molecular research have produced a highly effective, non-acidic anti-inflammatory.

Relifen. Each tablet is made of $500 \mathrm{mg}$ nabumetone, a non-steroidal anti-inflammato proven in numerous double blind studies to $b$ effective as other benchmark NSAIDs. Yet its route of action is totally different.

Relifen is a non-acidic pro-drug. In the stomach, it is relatively inactive. It is absorbed from the duodenum, into the portal blood sup Finally, in the liver, it is metabolised into a po inhibitor of prostaglandin synthesis. 


\section{Relieving his pain is pretty sporting of you, old chap. But do you have to get him high on acid?}

The acrive metabolite penetrates the synovial fluid to reach the inflamed site, giving effective relief of symptoms.

Excretion is by the kidneys, so gastrointestinal damage through biliary recirculation and reflux is unlikely.

For effective relief from pain and inflammation, with less chance of gastro-intestinal discomfort, you now have an ideal choice. Relifen.

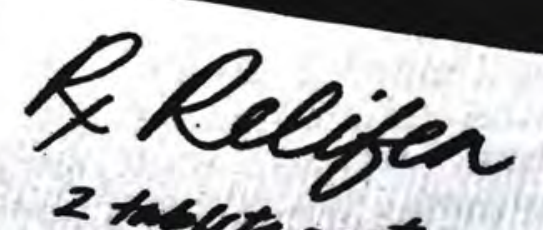




\title{
THE EFFECT OF DIETARY CHOLESTEROL ON PLASMA CHOLESTEROL LEVELS
}

\author{
Mieke Faber
}

Eggs, and therefore dietary cholesterol, play an important role in the diets of many athletes. Especially weight training athletes are prone to supplement their diets with eggs in order to increase the protein content of the diet.

Since as early as the 1940's the controversy on cholesterol intake exists. In the 1940's experiments were done which showed that cholesterol feeding resulted in increased plasma cholesterol levels. ${ }^{29}$ However, a few years later Keys et al (1956) came to the conclusion that in adult men the serum cholesterol level is essentially independent of the cholesterol intake over the whole range of natural human diets. ${ }^{22}$ This was confirmed by studies that indicated that there was no correlation between dietary cholesterol and plasma cholesterol levels..$^{25,40}$

Although no correlation was found between whole egg intake and plasma lipid levels in free living subjects, ${ }^{19}$ contro-

\section{Mieke Faber \\ Research Institute for Nutritional Diseases Medical Research Council}

versial results have been reported on the effect of egg feeding. While no changes in plasma cholesterol levels were observed after the addition of eggs to the habitual $\operatorname{diet}^{17,23,33,36,38}$ or an experimental diet ${ }^{15}$ of normal or uraemic patients, ${ }^{20}$ other studies reported an increase in plasma cholesterol levels after egg feeding on the habitual $\operatorname{diets}^{3,35,39}$ or experimental $\operatorname{diets}^{28}$ or on liquid formula diets. ${ }^{1}$ The increase in plasma cholesterol levels was greater in middle aged men as compared to younger men. ${ }^{39}$

Volunteers were grouped in two groups. The one group showed significant increases in plasma cholesterol levels after eating three eggs daily for ten weeks and a significant decrease within two weeks of cross over to eating no eggs. The other group showed a significant decrease in plasma cholesterol levels after eating no eggs for 12 weeks, but when crossing over to three eggs daily, there was no increase in plasma cholesterol levels. ${ }^{18}$

Fifty-six men were given a cholesterol free formula diet. During this period there was a decrease in plasma cholesterol levels. After the cholesterol free period they were divided into four groups who received a formula diet containing either $0,106,212$ or $317 \mathrm{mg} \mathrm{chol} /$ $1000 \mathrm{kcal}$ for a period of six weeks. The ingestion of cholesterol resulted in a linear increase in plasma cholesterol levels over the whole range of cholesterol feeding. Each 100 $\mathrm{mg} \mathrm{chol} / 1000 \mathrm{kcal}$ of the diet resulted in a $12 \mathrm{mg} / 100 \mathrm{ml}$ increase in serum cholesterol levels. $^{27}$ It is expected that further increases in dietary cholesterol in the abovementioned study would have no further effect on the plasma cholesterol levels since it was shown by Connor et $a l^{10}$ that the addition of $475 \mathrm{mg}$ or 1425 mg cholesterol had the same elevating effect on plasma cholesterol levels. It has also been shown that the plasma cholesterol levels increased sharply when the daily cholesterol intake was between 13 $\mathrm{mg}$ and $634 \mathrm{mg}$. There was no further increase in plasma cholesterol levels after the ingestion of 1300 to $4500 \mathrm{mg}$ cholesterol and the dose-response curve was relatively flat. ${ }^{2}$

Addition of two eggs had no effect on plasma cholesterol levels, but when the two eggs were removed from the diet there was a significant drop in plasma cholesterol levels after 12 weeks. ${ }^{16}$ When eggs were removed from the diets of 
people who habitually consume at least one egg per day, there was a small but significant decrease in plasma cholesterol levels. ${ }^{4,7}$

\section{EFFECT OF DIETARY CHOLESTEROL ON PLASMA LIPOPROTEINS}

Plasma cholesterol is not the only variable to be looked at. Although there was no significant change in plasma cholesterol levels when one egg was added to the habitual diet of lacto-ovo-vegetarians, there was a significant increase in plasma LDL-cholesterol. ${ }^{36}$ While ingesting a liquid formula diet containing $5000 \mathrm{mg}$ cholesterol in the form of egg yolk $^{1}$ or when adding cholesterol to the normal $\operatorname{diet}^{3}$ there was a significant increase in plasma cholesterol levels, mainly due to an increase in LDL-cholesterol levels. The rise in LDL-cholesterol levels may be explained by an increase in LDL-cholesterol formation. ${ }^{30}$ The consumption of a large number of eggs, whether or not it leads to an increase in plasma cholesterol levels, does alter the properties in human HDL, namely it increases the binding capacity. ${ }^{26}$

\section{TYPE OF FAT IN THE DIET}

It has been shown that the effect of dietary cholesterol is dependent on the type of fat in the diet. In two cross over studies, healthy students received a diet either rich in linoleic acid $^{5}$ or poor in linoleic acid $^{6}$ with two levels of dietary cholesterol (either $200 \mathrm{mg}$ or $600 \mathrm{mg}$ ). The high cholesterol diet was obtained by providing 2 egg yolks per day. Supplementation of the linoleic acid rich diet with the egg yolk cholesterol caused a significant rise in plasma cholesterol levels of about $11 \mathrm{mg} / 100 \mathrm{ml}$. This rise in plasma cholesterol was however much smaller than the rise of $26 \mathrm{mg} / 100 \mathrm{ml}$ which occurred when the linoleic acid poor diet was supplemented with the egg yolk cholesterol, indicating that the effect of cholesterol is clearly dependent on the type of fat in the diet. ${ }^{5.6}$ When cholesterol was added to either a diet with a low or a high $P / S$ ration, there was an increase in plasma TC. The increase in plasma cholesterol was slightly less on the low $\mathrm{P} / \mathrm{S}$ diet as compared to that on the high P/S diet, but it should be kept in mind that the overall plasma cholesterol levels (with or without cholesterol) were higher on the diet with the low $\mathrm{P} / \mathrm{S}$ ratio. ${ }^{41}$

In another cross over study, the effect of changes in dietary cholesterol intake as well as changes in the type and amount of fat was studied. When the subjects switched from a control diet $(42-45 \%$ fat, $P / S$ $0,3-0,5,2$ eggs) to a fat modified diet $(35 \%$ fat, $P / S 1,0)$ also containing two eggs, the serum cholesterol decreased with $29 \mathrm{mg} / 100 \mathrm{ml}$. When the eggs were omitted from the fat modified diet the serum cholesterol decreased with an additional $7 \mathrm{mg} / 100 \mathrm{ml}$. When the control diet was followed up by the modified fat diet containing no eggs, the decrease in serum cholesterol levels was 41 $\mathrm{mg} / 100 \mathrm{ml}$. When eggs were returned to the fat modified diet, the serum cholesterol levels increased by $20 \mathrm{mg} / 100$ $\mathrm{ml}$. The results of this experiment suggest that smaller percentage changes in the type and amount of dietary fat have a similar or greater effect on serum cholesterol than a relatively greater change in dietary cholesterol. ${ }^{8}$ This is in contrast with earlier studies. In one of these studies it was shown that the effect of changes in dietary fat composition was smaller than the effect caused by changes in dietary cholesterol. ${ }^{12}$ Plasma cholesterol level increased when subjects con-sumed a cholesterol rich formula diet. When the saturated fat content of this diet was decreased, there was no change in the plasma cholesterol levels due to cholesterol feeding. ${ }^{11}$ Although no changes in HDL-C were found in the study done by Chenoweth, ${ }^{8}$ it was found that the increase in plasma cholesterol which occurred after a simultaneous increase in dietary cholesterol and fat, while the $\mathrm{P} / \mathrm{S}$ ratio of the diet remained the same, was due to an increase in LDL$\mathrm{C}$ as well as HDL-C. ${ }^{9}$

Either $750 \mathrm{mg}$ ( 3 eggs) or $1500 \mathrm{mg}$ cholesterol (6 eggs) was added to diets with a P/S ratio that ranged between 0,25 and 2,5 . When the $P / S$ ratio was either 0,25 or 0,4 , addition of 3 eggs to the diet caused increases in both plasma cholesterol and LDL-C levels. These increases were increased further when 6 eggs were added to the diet. When the $\mathrm{P} / \mathrm{S}$ ratio of the diet was 0,8 , addition of 3 eggs to the diet had no effect on plasma cholesterol or LDL-C levels, but these levels increased after addition of 6 eggs to the 
diet. Addition of either 3 eggs or 6 eggs had no effect on the plasma cholesterol and LDL-C levels when the $\mathrm{P} / \mathrm{S}$ ratio of the diet was 2,5. This study indicated that both the cholesterol content and the $\mathrm{P} / \mathrm{S}$ ratio of the diet are important in determining plasma cholesterol and LDL-C levels. ${ }^{37}$

Fat plays and important role in determining the effect of dietary cholesterol on plasma cholesterol levels and has been demonstrated by the fact that subjects who have previously been classified as hyperresponders showed no response to a moderate cholesterol intake while they consumed a low fat, high fibre diet with a relatively high $\mathrm{P} / \mathrm{S}$ ratio $(1,1: 1,5)$. The effect of eating nine, zero and nine eggs per week over a period of three consecutive months was studied in subjects who had previously been classified as hyper-responders to cholesterol intake. During the study they consumed a high fibre, low fat diet with a relatively high $\mathrm{P} / \mathrm{S}$ ratio. There were no significant differences between the different dietary periods indicating that hyperresponse to moderate cholesterol intake is not apparent in people eating a low fat, high fibre diet. ${ }^{13}$

\section{ENERGY AND CHOLESTEROL FEEDING}

It seems as if not only the type and amount of fat in the diet have an effect on the plasma cholesterol response on cholesterol feeding, but energy intake also seems to be important. The influence of a low- energy diet when associated with a high cholesterol intake was investigated in a cross over study. When two whole eggs and two egg yolks were added to the habitual diet of seventeen normal men during the first phase of the study, no changes in plasma cholesterol occurred. When these same men were put on a low-energy diet during the second phase of the study there was only a small but insignificant decrease in plasma cholesterol levels due to adaptation to a high cholesterol intake. However, when the consumption of four eggs per day was associated with a low energy intake during phase 1 , there was an increase in plasma cholesterol levels which normalized in the second part of the study when they returned to their habitual energy intake. ${ }^{24}$

\section{EXERCISE AND CHOLESTEROL FEEDING}

It seems as if exercise also influences the effect of cholesterol feeding on plasma cholesterol levels. It has been shown that aerobic conditioning in men might prevent a significant increase in plasma TC levels at moderate and high cholesterol intakes. ${ }^{34}$ Body builders are a group of weight training athletes who supplement their diets with eggs. Over a range of from 0 to 12 eggs per day, there was no correlation between egg intake and plasma cholesterol levels. Despite their very high cholesterol intake they did not have elevated plasma cholesterol levels. ${ }^{14}$

\section{HYPO- AND HYPER- RESPONDERS}

There was a considerable individual variation in the response of plasma cholesterol levels to changes in dietary cholesterol. ${ }^{8,15,18,23,31,41}$ From this wide variation it is clear that people can be categorized into hyperresponders and hypo-responders. What the classification of a hyper- and a hyporesponder is, is not quite clear. In the study done by $\mathrm{Oh}$ and Miller ${ }^{31}$ hyper-responders were defined as those subjects whose plasma cholesterol levels increased by more than $8 \%$ on cholesterol feeding, while hypo-responders were defined as those subjects who showed no change or an increase of less than $5 \%$ in plasma cholesterol levels on cholesterol feeding. Hyper-responders can also be classified as those subjects whose plasma cholesterol levels are in the upper quartile on cholesterol feeding while hypo-responders are those whose plasma TC levels fall in the lower quartile on cholesterol feeding. ${ }^{21}$

Although it seems as if exercise has a protective effect against egg feeding, ${ }^{14,34}$ too little evidence is available to justify the high egg consumption of athletes. It is recommended that athletes follow the same recommendations as the general population. It is therefore recommended that the daily cholesterol intake should not exceed $300 \mathrm{mg}$ per day. ${ }^{32}$

\section{REFERENCES}

1. Applebaum-Bowden A, Hazzard WR, Cain J, Cheung MC, Kushwaha RA, 
Albers JJ. Short term egg yolk feeding in humans. Atherosclerosis, 1979; 33: 385-396.

2. Beverdige JMR, Connell WF, Mayer $\mathrm{GA}$, Haust $\mathrm{HL}$. The response of man to dietary cholesterol. J Nutro, $1969 ; 60: 61-65$.

3. Beyen AC, Katan MB. Effect of egg yolk feeding on the concentration and composition of serum lipoproteins in man. Atherosclerosis, 1985; 54: $157-166$

4. Beyen AC, Katan MB. Reproducibility of the variations between humans in the response of serum cholesterol to cessation of egg consumption. Atherosclerosis, 1985; 57: 19-31.

5. Bronsgeest-Schoute DC, Hautvast JGAJ, Hermus RJJ. Dependence of the effects of dietary cholesterol and experimental conditions on serum lipids in man. I: Effects of dietary cholesterol in a linoleic acid-rich diet. Am J Clin Nutr, 1979; 32: 2183-2187.

6. Bronsgeest-Schoute DC, Hermus RJ, Dalinga-Thie GM, Hautvast JGAG. Dependence of the effects of dietary cholesterol and experimental conditions on serum lipids in man. II: Effects of dietary cholesterol in a linoleic acid-poor diet. Am J Clin Nutr, 1979; 32: 2188-2192.

7. Bronsgeest-Schoute DC, Hermus RJ, Dallinga-Thie GM, Hautvast JGAJ. Dependence of the effects of dietary cholesterol and experimental conditions on serum lipids in man. III: The effect of serum cholesterol of removal of eggs from the diet of free living habitually egg-eating people. Am J Clin Nutr, 1979; 32: 21932197.

8. Chenoweth $\mathbf{W}$, Ullmann $\mathbf{M}$, Simpson $R$, Leveille $G$. Influence of dietary cholesterol and fat on serum lipids in men. J Nutr, 1982; 111: 2069-2080.

9. Cole TG, Patsch W, Kuisk I, Gonen $B$, Schonfeld $G$. Increases in dietary cholesterol and fat raise levels of apoprotein E-containing lipoproteins in the plasma of man. $J$ Clin Endocrinal Metab, 1983; 56: 1108-1115.

10. Connor WE, Hodges RE, Bleiler RE. The serum lipids in men receiving high cholesterol and cholesterol free diets. J Clin Invest, 1961; 40: 894-901

11. Connor WE, Hodges RE, Bleiler RE. Effect of dietary cholesterol upon serum lipids in man. J Lab Clin Med, 1961; 57: 331-342.

12. Connor WE, Stone DB, Hodges RE. The interrelated effects of dietary cholesterol and fat upon human serum lipid levels. J Clin Invest, 1964; 43: 1691-1696.
13. Eddington JD, Geekie M, Carter R, Benfield L, Ball M, Mann J. Serum lipid response to dietary cholesterol in subjects fed a low-fat, high fibre diet. Am J Clin Nutr, 1989; 50: 5862.

14. Faber $\mathbf{M}$, Benadé AJS, van Eck $M$. Dietary intake, anthropometric measurements and blood lipid values in weight training athletes (body builders). Int J Sports Med, 1986; 7: 342346.

15. Flaim E, Ferreri LF, Thye FW, Hill JE, Ritchey SJ. Plasma lipid and lipoprotein cholesterol concentrations in adult males consuming nomal and high cholesterol diets under controlled conditions. Am J Clin Nutr, 1981; 34: 1103-1108.

16. Flynn MA, Anderson A, Rutledge M, Nolph GH, Krause G, Ellersieck MR. Eggs, serum lipids, emotional stress and blood pressure in medical students. Arch Environmental Health, 1984; 39: 90-95.

17. Flynn MA, Nolph GB, Flynn TC, Kahrs R, Krause G. Effect of dietary egg on human serum cholesterol and triglycerides. Am J Clin Nutr, 1979; 32: 1051-1057.

18. Flynn MA, Nolph GB, Osio Y, Sun GY, Lanning B, Krause G, Dally JC. Serum lipids and eggs. J Am Diet Assoc, 1986; 86: 1541-1548.

19. Green MS, Jucha E. Association of serum lipids with coffee, tea, and egg consumption in free-living subjects. J Epidemiol Comm Health, 1986; 40: 324-329.

20. Green EM, Perez GO, Hsia SL, Crary M. Effect of egg supplement on serum lipids in uraemic patients. $J$ Am Diet Assoc, 1985; 85: 355-357.

21. Katan MB, Beyen AC, de Vries JHM, Nobels A. Existence of consistent hypo- and hyper-responders to dietary cholesterol in man. $A m J$ Epidemiol, 1986; 123: 221-234

22. Keys A, Anderson JT, Mickelsen O, Adelson SF, Fidanza F. Diet and serum cholesterol in man: Lack of effect of dietary cholesterol. $J$ Nutr, 1956; 59: 39-56.

23. Kummerow FA, Kim Y, Hull, Polland J, Hinov P, Dorossiev DL, Valek $J$. The influence of egg consumption on the serum cholesterol level in human subjects. Am J Clin Nutr, 1977; 30: 664-673.

24. Lacombe CR, Corraze GR, Nibbelink MM, Boulze D, Douste-Blazy $P$, Camare R. Effects of low-energy diet associated with egg supplementation on plasma cholesterol and lipoprotein levels in normal subjects: results of a cross over study. $B r J$ Nutr, 1986; 56: 561-575.
25. Liebman M, Bazzarre T. Plasma lipids of vegetarian and non-vegetarian males: effect of egg consumption. Am J Clin Nutr, 1983; 38: 612619.

26. Mahley RW, Innerarity TL, Bersot TP, Lipson A, Margolis S. Alterations in human high density lipoproteins, with or without increased plasma cholesterol induced by diets high in eholesterol. Lancet, 1978; 11: 807 809.

27. Mattson FH, Erckson BA, Kigman AM. Effect of dietary cholesterol in man. Am J Clin Nutr, 1972; 25: 589. 594.

28. McMurry MP, Connor WE, Lin DS, Cerqueira MT, Connor SL. The absorption of cholesterol and the sterol balance in the Tarahumara Indians of Mexico fed cholesterol-free and high cholesterol diets. Am J Clin Nutr, 1985; 41: 1280-1208.

29. Messinger WJ, Porowska Y, Steele JM. Effect of feeding egg yolk on serum cholesterol levels. Arc Int Med, 1950; 86: 189-195.

30. Nestel PJ, Billington T. Increased transport of intermediate density lipoprotein (IDL) with cholesterol loading. Metabolism, 1983; 32:320322

31. Oh SY, Miller LT. Effect of dietary egg on variability of plasma cholesterol levels and lipoprotein cholesterol. Am J Clin Nutr, 1985; 42: 421-431.

32. Op't Hof $L$. Consensus symposium: Dietary recommendations for the prevention of coronary heart disease. S Afr Med J, 1988; 74: 475476

33. Porter MW, Yamanaka W, Carlson SD, Flynn MA. Effect of dietary egg on serum cholesterol and triglyceride of human males. Am J Clin Nutr, 1977; 30: 490-495.

34. Quig DW, Thye FW, Richey SJ, Herbert WG, Clevidence BA, Reynolds LK, Smith MC. Effects of short term aerobic conditioning and high cholesterol feeding on plasma total and lipoprotein levels in sedentary young men. Am J Clin Nutr, 1983; 38: 825-834.

35. Roberts SL, McMurry MP, Connor WE. Does egg feeding(i.e. cholesterol) affect plasma cholesterol levels in humans? The results of a double-blind study. Am J Clin Nutr, 1981; 34: 2092-2099.

36. Sacks FM, Salazar J, Miller L, Foster JM, Sutherland M, Samonds KW, Albers JJ, Kass EH. Ingestion of egg raises plasma low density lipoproteins in free-living subjects. Lancet, 1984; 1: 647-649. 


\section{SASMA NEWS}

The 4th South African Sports Medicine Congress heralded a new era for sport in South Africa. All indications are that South Africa will be allowed to participate at international level again after years of isolation. This places a big responsibility on sportsmen and coaches and also demands proper medical care for our athletes to ensure that their preparation and participation are scientifically sound and that adequate care is being taken to prevent, treat and rehabilitate sport injuries. Medical Schools in South Africa have lagged behind the rest of the competing world in providing adequate postgraduate sports medicine training to doctors taking care of athletes.

During the past four years, the South African Sports Medicine Association played a significant role in education and dissemination of knowledge through the four Sport Medicine Congresses held in South Africa during the past eight years. Not only did we create a forum where young South African Sports Medicine Scientists could present their research, but we also invited leading Sports Medicine Physicians from all comers of the world to address us on various important aspects of Sport and Medicine.

The most recent Sports Medicine congress in Sun City from 24-27 April 1991 was no exception: we invited five international speakers to address us on various topics. The Sec- retary General of the International Federation of Sports Medicine (FIMS Federation Internationale Médico Sportive) attended our congress and announced that South Africa will be accepted as the 83rd member of this influential Sports Medicine body.

In order to stage international sports events in our country, we need to have an accredited analytic laboratory for doping control. Since South Africa has been active in this field since 1983 under the guidance of one of the world's best known doping control laboratories at King 's College in London, it will only be a formality to obtain international accreditation for our doping control facilities. We had the good fortune of having Dr David Cowan of London as one of our distinguished guests to evaluate our facilities and to advise us accordingly. Dr Cowan is head of the King's College
Doping Control and Information Centre in London and will be instrumental in advising the IOC Medical Commission about the South African situation.

We believe that South Africa will be able to accept the challenge of providing adequate medical support to our athletes. The South African Sports Medicine Association succeeded in bringing together all the disciplines involved in sports medicine and promoting cooperation between this multi-disciplinary team by making everybody concerned aware of their unique role. But this is not enough: South Afrioa needs more Sports Medicine training facilities to fulfil the needs of our top sportsmen that will soon be competing at international level. If the association succeeds in making South Africa more aware of our needs in this regard, it will be a major achievement! $\square$

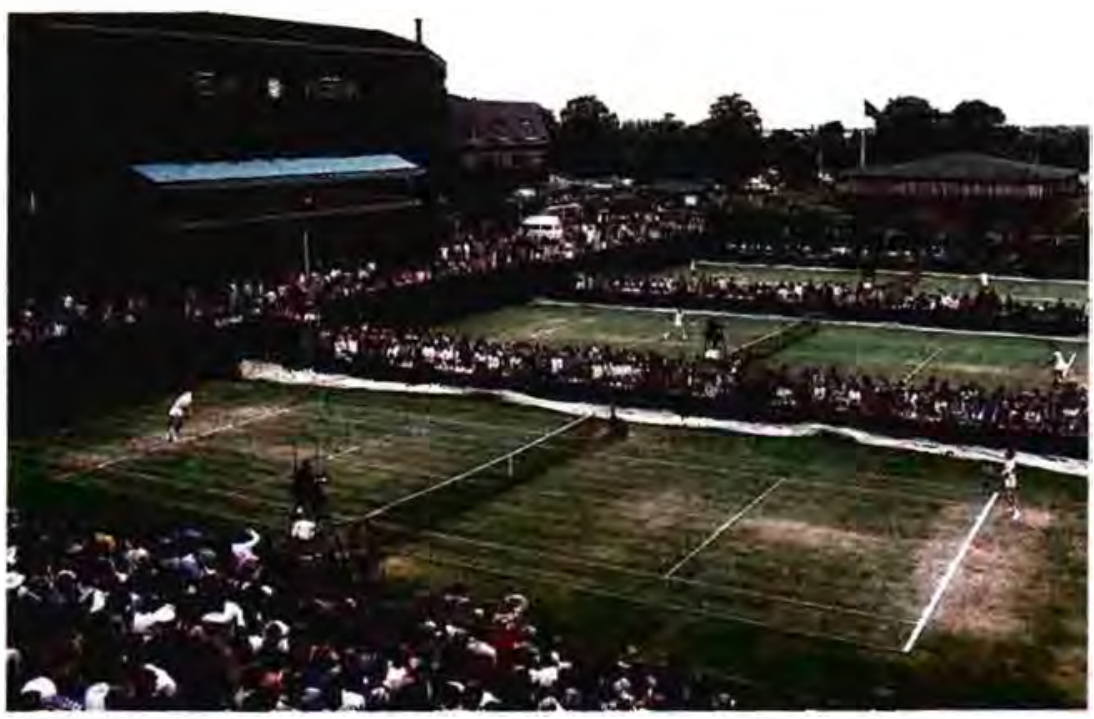




\title{
TREATMENT OF SOFT TISSUE INJURIES: THE FACTS ABOUT FRICTIONS
}

\author{
Craig A Smith
}

Keywords: Soft tissue injuries, scarring, deep transverse frictions, physiotherapy.

\begin{abstract}
The treatment of soft tissue injuries by deep transverse frictions (DTF) has been looked upon by various medical practitioners with a certain degree of circumspect. Although most physiotherapists and a few physicians stringently advocate its use, there are still those who are ignorant to its benefits. This paper attempts to bring to attention the expediency of DTF by providing a short overview of how the technique achieves its curative effect.
\end{abstract}

\section{INTRODUCTION}

The history of massage dates back to the times of ancient Babylonia, China and historical Roman days.' Great use for it was found as an effective method of treating systemic illnesses and other injuries. Nowadays, massage as we are familiar with, is used more for relaxation purposes and the relief of stress which stems

\section{Craig A Smith}

BSc Physiotherapy

BSC (Hons) Sports Science

16 V'redenhof

Carstens Road

Tamboerskloof

CAPE TOWN 8001 mostly from the lifestyles people lead. Although massage in this respect is very effective in creating a relaxed and calming, almost euphoric feeling, it clearly has no role to play in the treatment of soft tissue injuries.

There is, however, a certain massage technique with which physiotherapists and a good majority of their patients are familiar. It proffers certain relief with most soft tissue injuries, providing the patient is able to bear the excruciating pain which unfortunately goes hand in hand with it. Welcome to the facts about frictions; Deep Transverse Frictions!

Most medical practitioners, barring those who are athletes and whose injuries have benefited from it in some way, view DTF with a certain amount of scepticism and doubt. How can a massage technique resolve an injury when it seems to be doing more damage than good? How can the patient benefit from such a treatment which actually causes more pain than the injury itself? How can any sensible medical person ever have come to devise such a method which should not even be regarded safe as a torture technique? There is, however, an answer to this rhetoric and it lies with the comments of those patients who have endured the pain, yet witnessed the results when treated in this manner: It works so I'll bear it. No pain no gain.

DTF was viewed as early as 1948 as the only worthwhile manipulative treatment which could exert a beneficial effect on soft tissue lesions. Dr James Cyriax $^{2}$ has championed its cause for many years and now 
it is widely used by physiotherapists and recommended by other practitioners in the treatment of orthopaedic and sports related injuries. ${ }^{3,4}$

\section{THE THEORY OF DTF}

The specificity of DTF is such that when it is performed properly and with sufficient vigor, enough to bring the patient to tears and give reason to rename it crucifixions ${ }^{3}$, it penetrates deep to affected structures far below the skin surface, where other modalities would only exert their effect at a superficial level. ${ }^{1}$ It follows that massage, in this way, must be confined to tissues that respond to it, and that it must exert its effect at the exact site of the lesion. ${ }^{5}$

The aim of this technique is two fold; primarily to break down adhesions or fibrous scarring which develop during the bodies natural healing process following an injury, and secondly, to increase the mobility of those tissues and in so doing, improve their functional capacity. DTF is thus indicated in the treatment of muscle strains and tears, tendon lesions (tenosynovitis and tendonitis) and ligament sprains.

\section{APPLICATION OF DTF}

DTF is applied only to the area of injury with firm pressure across the grain of the tissues, be it a small concentrated spot or a longitudinal part of a muscle. ${ }^{6}$ The effects which promote a healing response are as follows:

- A traumatic hyperaemia is produced following a couple of minutes of DTF. The increase in bloody supply affords a degree of analgesia by the destruction of Lewis $P$ substances which are responsible for pain being felt. ${ }^{1}$ Once the session is over, the patient's pain is diminished and the structure hurts less when it is required to function. ${ }^{5}$

- DTF are applied at 90 degrees to the injured fibres causing a transverse movement of each fibre across the other. The action serves to break down the adhesive connections which bind the tissues together and restore free movement. $^{1}$

- Tissue perfusion is improved. ${ }^{1}$

- DTF stimulates the mechanoreceptor cells. Therefore, impulses from the moving parts take precedence over the afferent sensory stimuli, thus relieving pain. ${ }^{1}$

\section{TECHNIQUE OF DTF}

It is most important that the person, preferably a physiotherapist, who is giving DTF is familiar with the correct application of the technique. Before commencing, an accurate diagnosis of the injury based on the history, the site of the lesion and the response of the symptoms to specific testing procedures must be made so that the therapist can determine whether the injury will benefit from the technique. The structure to be treated in this way must be isolated and positioned in the correct manner. Whether the finger or thumb pads or the elbow are to be used, the two skin surfaces must move in unison to prevent a friction injury to the skin i.e. a blister. The fingers or thumb should be in a semi-rigid, flexed position and sweep over the structure with the action controlled at the wrist. Patient comfort and structure position must be maintained throughout the treatment.

\section{MUSCULAR INJURIES}

Muscles contract (concentrically) by shortening and broadening. An injury to a muscle, be it a strain or tear, will eventually result in a fibrous scar forming among the fibres. This reduces movement and causes pain when the muscle contracts. The effect of DTF in the acute stage is thus to mobilise the fibres in a transverse direction and prevent these adhesions from developing. In the chronic muscle tear, DTF act to break down these adhesions and improve the muscle's contracting mobility.

Passive longitudinal stretching plays an integral role in the management of muscle injuries and is considered to be a vital tool in maintaining or improving fibre length and flexibility. However, there is no clear proven evidence to indicate whether stretching should be incorporated at the earliest stage of treatment or whether it should only be introduced in the latter stages when the injury shows signs of healing.

The rationale of an early introduction proposes that 
muscle fibre length needs to be improved and capitalised on the increased mobility which DTF bring about, and that early stretching directly after DTF is thought to achieve this result. A somewhat contras-ting opinion exists supporting the argument that stretching should begin at the end stage of treatment. A longitudinal stretch on the muscle lengthens the fibres and in so doing causes them to come into closer contact with each other. This contributes towards further adhesive binding of the fibres and reduces flexibility. Thus, early stretching would seem to defeat the aims of DTF, being to break down the adhesions and transversely mobilise the fibres. As an alternative to early stretching, active isometric contractions of the muscle in the shortened range are advocated to maintain transverse moblity. ${ }^{2}$

\section{TENDON INJURIES}

Logic would have it that any overuse friction injury should not be treated by the same method that caused it. In tendon lesions, this might seem the case, yet DTF is known to achieve quick and satisfying results. In tenosynovitis, DTF performed in a too and fro motion serve to smooth the surfaces off, and although longitudinal friction is the causative action, the curative frictions are in the transverse plane. ${ }^{2}$

In tendonitis, DTF act in much the same way as for muscle injuries by breaking down the adhesions within the tendon.

\section{LIGAMENT INJURIES}

The action of DTF in ligament injuries is to breaking up adhesions either in the ligament itself or binding it to the bone and so increase mobility. In the acute phase, only one to two minutes of mild DTF is necessary, whereas in chronic sprains, up to fifteen minutes of treatment can be given. It is important when giving DTF to ligaments that the affected ligament is positioned in a stretched position. Failure to bring about complete healing can cause respraining for the ligament due to reduced strength and proprioceptive instability.

\section{CONTRA-INDICATIONS TO DTF}

The following are conditions where DTF are not indicated and should never be attempted:

- Bacterial inflammation;

- Calcific deposits in muscles or tendons;

- Inflammatory arthritides;

- Bursitis;

- Nerve injuries;

- Traumatic arthritis of the elbow;

- Thrombosis simulating a soft tissue injury.

\section{CONCLUSION}

The topic of DTF with respect to how and why it works is by no means an open and shut case. Evidence detailing its effectiveness and success as a manipulative technique (and therefore justifying its usage in the treatment of soft tissue injuries) has been explained and is of course open to discussion. Moreover, the testimonies among users and receivers of the technique mostly agree that it does work, and very well at that.

In order to satisfy the ever questioning human mind with feasible answers as to how and why it does work, it is understandable that further experimentation, perhaps with pathological or magnetic resonance imaging investigations, needs to be performed in order to be able to draw firm scientific conclusions. However, science, which is its custom, has only managed to fuel the debate on the efficacy of DTF and is unable to at times provide the most suitable answers. Therefore, we as explorers of its domain should not let our minds insistence for proof cloud the reality that, although human reasoning might dent the efficacy of DTF, its often astounding clinical results has its own way with God's marvellous creation. Man can only stand by and wonder (in pain) just how and why and for what reasons the facts about frictions add up.

\section{REFERENCES}

1. Kamenetz HL. History of Massage. In: Manipulation, Traction and Massage, Ed. Basmajian JV. Williams and Wilkins, Baltimore, 1985.

2. Cyriax JH. Textbook of Orthopaedic Medicine Vol 2. Bailliere Tindall, London, 1980; 3-36.

3. Noakes TD. Lore of Running. Oxford University Press, Cape Town, 1987.

4. Corrigan B and Maitland GD. Practical Orthopaedic Medicine. Butterworths, London, $1983 ; 26$. $\square$ 


\title{
THE COMRADES MARATHON AS SEEN THROUGH THE EYES OF A PHYSIOTHERAPIST
}

\author{
Joyce Morton
}

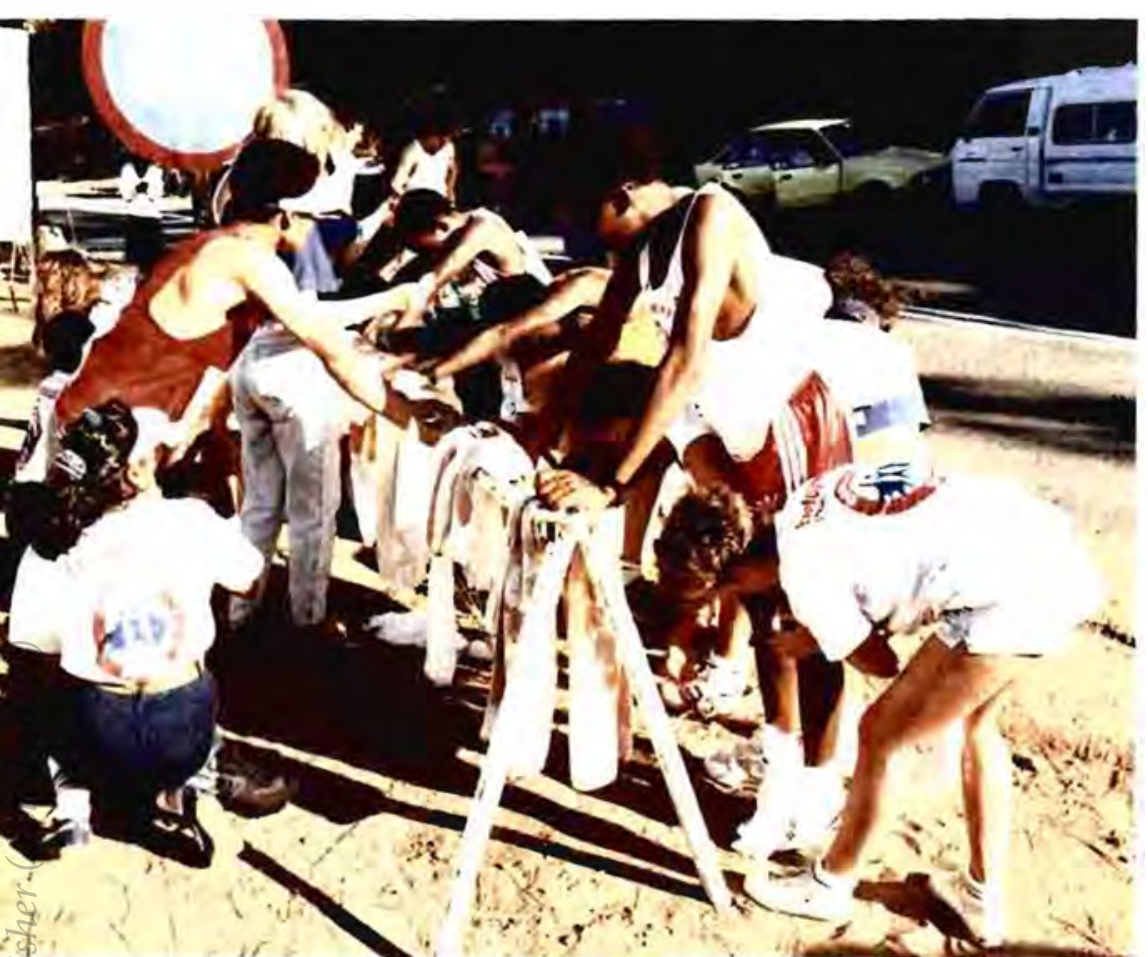

For the physiotherapist, Comrades Marathon starts many weeks before the event as veteran runners and novices pour into our practices with minor injuries, usually created by incorrect training methods. One of our major roles during this time is to encourage runners to ease back on their training. Novices especially, seem to think that if they do not run right up to the day before the race, they will not be able to run from Pietermaritzburg to Durban. Psychological support and counselling about glycogen storage and fluid intake are of utmost importance was the slowest speed he should do. The organizing committee has now accepted that we perform a major service on the day of the race because there will always be runners undertrained or overtrained who benefit from the service we offer.

The Comrades Committee consists of Judy McKeon, Kay Morely and myself. Our volunteers come from the 3rd and 4th year physiotherapy students of the University of Durban-Westville and Natal physiotherapists. There are 7 "Elastoplast" stations along the route and each station has Smith and Nephew staff, a trained nursing sister, recorders and physiotherapists. Sixty physiotherapy volunteers helped this year.

Comrades Marathon day starts in the early hours of the morning for some of the physiotherapists in private practice who assist their patients by strapping them before they leave for the race. For the rest, the day starts from 5 o'clock onwards depending on how far the station is from home. My rule is to be dressed and ready by $6 o^{\prime}$ clock, to watch the starn of the race on TV and then tc head for Inchanga $48 \mathrm{kms}$ from Durban. Even at this hour without a "Refreshment" sigr stuck to my windscreen, 
would not be allowed onto the Old Main Road as the police are already on duty.

Our working area has been cornered off by Peter Hammond, the Smith and Nephew man. All we have to do is put up banners to alert the runners to the fact that there are physiotherapists ahead of them. Tables are set up with hundreds of rolls of elastoplast, Antichafe, cottonwool, elastozoff, blister plasters and this year, tubes of Voltaren donated by Ciba-Geigy.

Lastly our long rail is set up near the road. This rail is about a meter high. It reminds me of the cowboys who used to tie their horses on similar rails outside the Old West Bars. The runners lean on the rail in order that their legs, backs or necks might be treated without their having to lie down. Two large mats are placed on the ground for runners with blisters, headaches, painful feet or ankles as we cannot treat these ailments unless the patient sits or lies down.

We just have time to eat a delicious breakfast cooked and donated by Peter, when the first runners appear. To them the Inchanga Hill is no threat and we clap to congratulate them as they run past. However, it is not long afterwards that the first of the runners stops to ask for help at our station.

We offer three main services; to rub aching muscles using Anti-chafe; to rub using ice or to strap using elastoplast. The ice is by far the most popular treatment. Hundreds of polystyrene cups are filled with water and frozen. This means that the physiotherapist does not get a frozen hand as she rubs the ice onto a runner. I am sure that any physiotherapist reading this will tell me that two minutes of rubbing with ice can have no real effect on a runner. Our investigations done over the years have shown that ice does help and more and more runners are asking to be treated with it.

At the Inchanga station Judy and I always take on the task of strapping. Together this year, over a period of approximately one and a half hours, we strapped 160 parts of

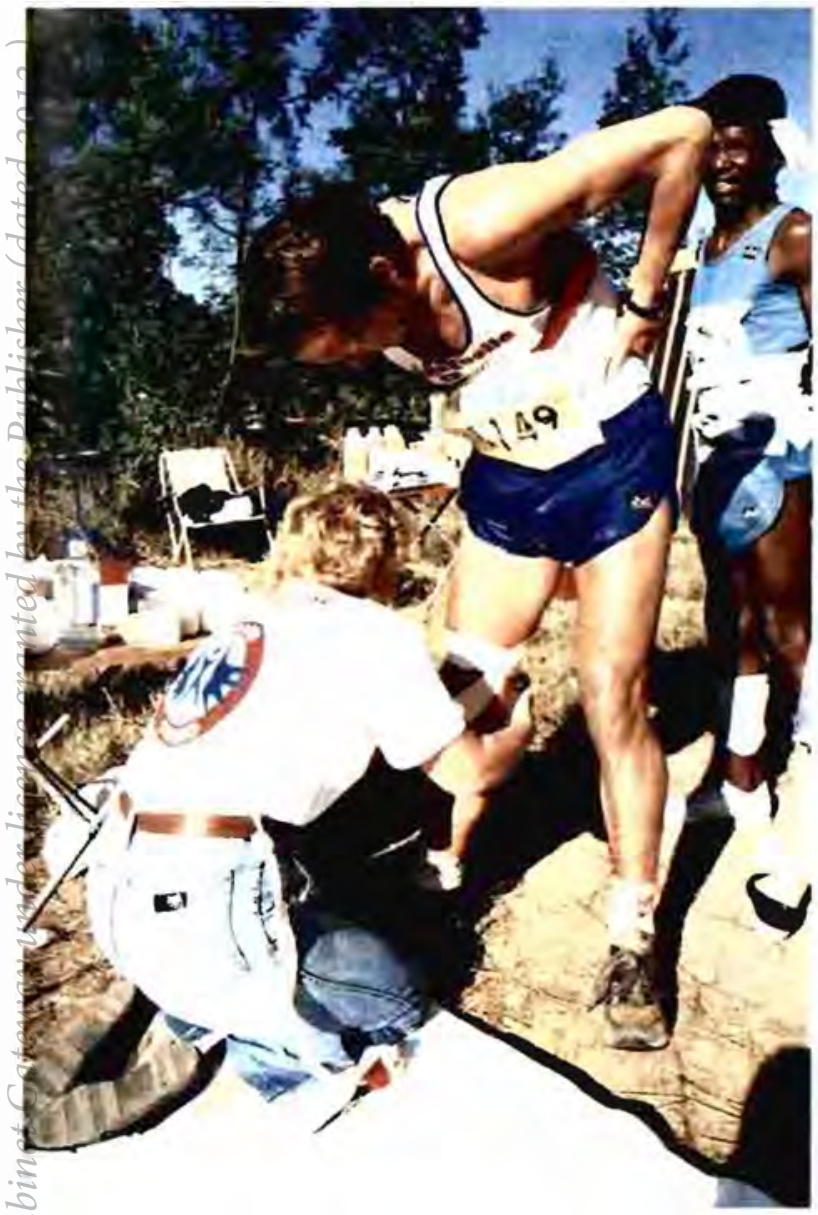

This year .... 13988 runners started

the race, 12081 finished the race, 1028

runners were admitted to tents for

medical treatment

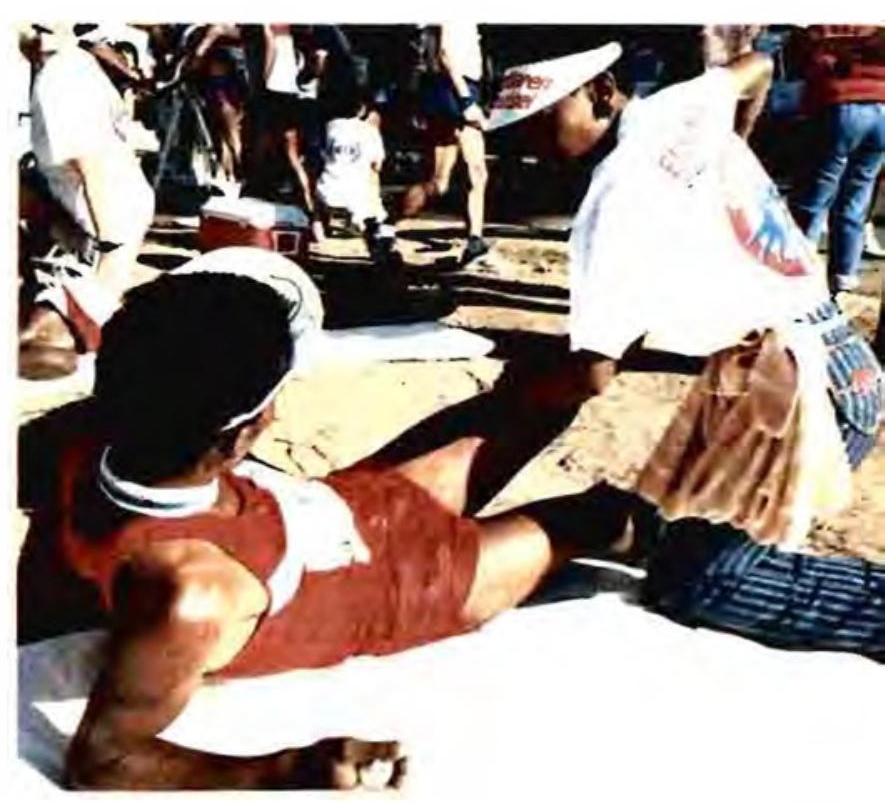


the body. Most of the problems are knees caused we are sure, by over training or incorrect shoes. In order to reach the knees, one has to kneel. No one has ever done research on the frequency of patella tendonitis in physiotherapists kneeling on the road during an ultra marathon!

Because this year was a down run, as expected, many of the runners complained of an Ilio-tibial band friction syndrome. Our advice to these runners was to walk down the hills backwards. Most friction of the band is at 30 degrees of flexion and this does not happen when one walks backwards. It must be remembered that many of these runners are trying to beat the 11 hour gun, and they definitely have the time to walk down hills.

The runners stopping at our station increase to an almost unmanageable number. Physiotherapists are seen to be stretching cramped hamstrings, mobilizing painful backs, giving advice, kneeling on the road to rub a calf, bending over to reach a painful knee, helping a runner remove a shoe, kneeling on the mat to mobilize a cervical spine, running next to a runner to give him some anti-chafe, removing rubbing creams with Elastozoff so that Elastoplast might stick and generally managing to achieve the impossible. Then suddenly, as fast as they appear, they all disappear except for one or two runners who have thrown in the towel and are waiting for the Comrades bus to take them to Durban.

I battle to rise from the road - obviously age has something to do with it - and take a sip of coke which tastes like nectar. We wearily tidy up, pack our cars and head for home knowing that as we do, so there are thousands of runners grateful to the physiotherapists who have in some small way helped them to achieve their goal of completing a Comrades Marathon.

One feels my story should end here, but it does not. Some of us drive down to Kings Park and work in the Red Cross Tend until $8 \mathrm{pm}$. Our main function is to help break the excruciating cramps which the over- or under-hydrated runners get when they stop running. To work in the Red Cross or the Medical Tent is an experience no medical person involved in the treating of marathon runners should miss. It always reminds me of a battle station. The work done by the hundreds of volunteers is heartwarming and just reinforces what kindness man can do to man ... but that's another story to be written some other time.

This year, the official figures are that 13988 runners started the race, 12081 finished the race, 1028 runners were admitted to the Medical, Red Cross or St Johns Tents for medical treatment.

Our as yet unconfirmed figures show that the physiotherapists in the seven Smith and Nephew stations treated approximately 4000 ailments. The Comrades House has been inundated with telephone calls from runners all over the country, asking that the physiotherapists be thanked for the work they do on Comrades Day. It really makes it all worth while. $\square$
[S3] V/3.1/62, V/3.1/238

W.F.I. H/34/128

\section{TILCOTIL ${ }^{\circledR}$}

\section{Components:}

TENOXICAM $20 \mathrm{mg}$

\section{Indications:}

Symptomatic treatment of the following painful inflammatory and degenerative disorders of the musculoskeletal system: rheumatoid arthritis; osteoarthritis ankylosing spondylitis; extraarticular disorders, e.g. tendinitis, bursitis, periarthritis, gouly arthritis (for tablets)

\section{Dosage:}

$20 \mathrm{mg}$ once daily at the same time each day. The parenteral form is used for one or two days. For treatment initiation in acute gouty arthritis $40 \mathrm{mg}$ (2 tablets) once daily for two days followed by $20 \mathrm{mg}$ once daily for a further five days is recommended.

\section{Contra-indications:}

Known hypersensitivity to the drug. Patients in whom salicylates or other nonsteroidal anti-

inflammatory drugs (NSAIDs) induce symptoms of asthma, rhinitis or urticaria. Patients who are suffering or have suffered from severe diseases of the upper gastrointestinal tract, including gastritis, gastric and duodenal ulcer. Before anaesthesia or surgery, 'TILCOTIL' should not be given to patients at risk of kidney failure, or to patients with increased risk of bleeding.

Concurrent treatment with

salicylates or other NSAIDs should be avoided.

Pregnancy and lactation

\section{Precautions:}

Simultaneous treatment with anticoagulants and/or oral antidiabetics should be avoided unless the patient can be closely monitored.

Renal function (BUN, creatinine, development of oedema, weight gain, etc.) should be monitored, when giving a NSAID to the elderly or to patients with conditions that could increase their risk of developing renal failure.

\section{Packs:}

Tablets 20 mg: 10's, 30's Vial pack containing 1 vial active substance and 1 ampoule water for injection. 